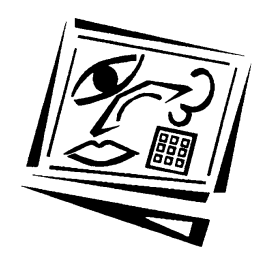

\title{
Teaching Teachers for the Future (TTF): Building the ICT in education capacity of the next generation of teachers in Australia
}

\author{
Geoff Romeo \\ Australian Catholic University \\ Margaret Lloyd \\ Queensland University of Technology \\ Toni Downes \\ Charles Sturt University
}

\begin{abstract}
The Teaching Teachers for the Future (TTF) project is a unique nationally significant project funded by the Australian Government through the Department of Employment, Education and Workplace Relations (DEEWR, Au\$8.8 million) and the Information and Communication Technology Innovation Fund (ICTIF). This 2011-2012 project has ambitiously attempted to build the ICT education (ICTE) capacity of the next generation of Australian teachers through its focus on pre-service teachers, teacher educators and the new Australian Curriculum. This paper will provide an overview of the project including a description of its genesis in a changing educational and political landscape, its structure and operations, its grounding in contemporary theory, the research opportunities it has engendered and its tangible outcomes.
\end{abstract}

\section{Introduction}

It is commonly accepted that information and communication technology (ICT) has had a lesser impact in classrooms than expected. An Australian study reported that:
After nearly five decades of computers in education, there is still confusion about the use of technology in classrooms and widespread reluctance to move beyond tokenistic use. There is not a universal, shared vision regarding the use of technology in the classroom and teachers are confronted with many theories and instructional designs and bombarded with confusing, even romantic, views of what the technology is capable of delivering. (Romeo, 2006; p. 150)

This situation has been shown in part to be due to: teachers' lack of confidence in the role of ICT in learning (Dawson, 2008); reluctance to change from more traditional teaching methods (Barak, 2007); and isolation of the "knowledge of technology" from pedagogical and discipline expertise (Lloyd \& Albion, 2007; Mishra \& Koehler, 2006).

The Teaching Teachers for the Future (TTF) project represents a once in a generation opportunity to engender substantive change in the ICT education (ICTE) capacity of pre-service teachers and redress the impediments to the broader use of ICT in classrooms noted in the literature. The primary aim of the project is capacity building and the systematic embedding of an ICTE dimension in pre-service teacher education 
curriculum, pedagogies, assessment, and professional experience. The TTF Project represents the first time that all 39 Australian higher education providers offering teacher education have come together to work collaboratively on building the ICTE capacity of pre-service teachers and teacher educators, university classroom and selfstudy resources; and, the national teacher education program accreditation framework and National Teacher Standards. It also represents the first time that the Schools Division of the national department of education, DEEWR (Department of Education, Employment and Workplace Relations), has funded a learning and teaching project in the higher education sector. The significance of this lies in a growing understanding by the Australian Government of the role of higher education in improving school educational outcomes. Rarely, if ever, in the history of school education in Australia, has initial teacher education been seen as a major partner in the work of improving teacher quality, despite its often being criticised in the popular media as contributing to the problems of poor teacher quality.

The TTF Project has been managed by a consortium of three national organisations: the Australian Council of Deans of Education (ACDE), Education Services Australia (ESA) and AITSL (Australian Institute for Teaching and School Leadership). ACDE represents the higher education sector; ESA is a schools-facing digital resource development agency; and AITSL is a recently established national regulatory authority responsible for National Teacher Standards and the national accreditation of initial teacher education programs. Each partner directs one of the three integrated components of the project to be addressed later in this paper.

This paper is intended to be a descriptive account of a major project in action. The view that "it is the privilege of historians - not contemporary commentators - to know how things ended, and therefore what they were" (Horne, 1964; p. 9) explains that contemporaneous reporting, as in this paper, makes critique difficult and reflection almost impossible. A fuller and more reflective evaluation will be conducted following the project's completion when measures of impact can be seen more clearly.

The role of this paper is thus to review the genesis of the project and set out the preliminary outcomes. Its data has come from a variety of sources including unpublished interim project surveys and reports, anecdotal observations and personal communication with project participants, as well as initial data provided by the research and evaluation working party. The authors' closeness to the project is not only an issue of time; they have also been intimately involved in the conceptualisation, development and implementation of the project and form the core national leadership group along with colleagues from ESA and AITSL. As such, the stance taken in this paper is one of participant observers.

This paper will conclude with a brief discussion of how the work initiated by the project might ideally be extended into the future. If there is a subtext here, it is about making informed decisions in the present to influence the future. The long term outcomes of the TTF Project relate to schooling and how teachers make use of the technologies of their times to enhance learning opportunities for their students. The authors accept that the real judgments about the TTF Project rest in the future.

\section{Genesis of the TTF}

The genesis of the project is set in the political and education period (2007-2010) when there was much national innovation and a number of key initiatives. It is important to 
identify and describe these major initiatives, as it was the weaving together of these that created a "space" from where the project was able to emerge. These initiatives were the Digital Education Revolution; the Australian Curriculum; and the National Teaching Standards (and accompanying national accreditation of initial teacher education programs).

The Digital Education Revolution

The National Partnership Agreement on the Digital Education Revolution (DER) announced by the Australian Government in May 2009 explained the DER's purpose as being to "contribute sustainable and meaningful change to teaching and learning in Australian schools to prepare students for further education, training and to live and work in a digital world" (DEEWR, n.d., para. 1). The DER first came to attention as part of a political campaign (Rudd, Smith \& Conroy, 2007) with the intention of achieving a student to computer ratio of 1:1 by the end of 2011 in Years 9 to 12. Since enacted, it has, as expected, been predominantly concerned with funding computer hardware and infrastructure in secondary schools. The DER initiative (DEEWR, n.d.) has also become increasingly aligned to the rollout of the National Broadband Network (NBN) and has adopted corollary strategies, supported by additional funding, earmarked for online curriculum resources and digital architecture and a recently announced online curriculum support package (Garrett, 2011). The ICT Innovation Fund, from which the TTF Project was funded, is an initiative of the DER. While obviously enabling the TTF project through funding, the DER has also created a climate of change and a renewed emphasis on the meaningful and broadly based integration of ICT in Australian classrooms.

The Australian Curriculum

The F (Foundation) to Year 12 Australian Curriculum can be best described as a work in progress [http://www.australiancurriculum.edu.au] under the direction of the Australian Curriculum Assessment and Reporting Authority (ACARA) established in May 2009. Up until the present time, education in Australia has been a matter determined by individual states and territories with previous attempts to establish a national curriculum being abandoned. This current iteration, based on the conceptual underpinnings outlined in the Melbourne Declaration, more correctly the Educational Goals for Young Australians (MCEETYA, 2008), will be progressively rolled out through three phases until 2015. Interestingly, ICT has been listed as a general capability in the Australian Curriculum and so was featured strongly in the Phase 1 syllabuses released, namely, English, Mathematics, History and Science. Importantly, the national government saw building consensus and support for the Australian Curriculum as a priority, and various projects and programs were funded to support this major initiative.

In initial discussions around the TTF Project, what was clear was that Australian teacher education institutions needed to embrace both the content and spirit of the Australian Curriculum, including its intention to position ICT within all learning areas as a general capability. While governments, regulatory authorities, and ACARA made this clear, by the end of 2010 no particular initiatives and no funding had been set aside to particularly address the significant curriculum changes that universities would need to undertake this work.

To this end, the TTF development team made the decision to focus on the Phase 1 learning areas with each participating institutions choosing one or two of the four learning area(s) they would address with the TTF Project. 
With reference to the subtext of this paper, the decision about the learning areas was patently one made "in the present" and determined largely by what was a priority of the national government and a required activity of the teacher education institutions. There was also a hope that the project might provide a template for how teacher education institutions might approach ICTE in the other Australian Curriculum learning areas as they were released.

National Professional Standards for Teachers

Another significant shift in the landscape came through the Australian Institute for Teaching and School Leadership (AITSL) founded on 1 January 2010. It has responsibility for: developing rigorous national professional standards for teachers and principals (released February 2011) (AITSL 2011); fostering and driving high quality professional development for teachers and school leaders; and, working collaboratively across jurisdictions and engaging with key professional bodies.

As with the curriculum previously discussed, the approval of teacher education courses had traditionally been a function of state and territory governments in Australia. With the establishment of AITSL, by 2015 there is to be national accreditation of pre-service teacher programs. The newly released National Professional Standards for Teachers comprise seven interdependent and overlapping standards grouped into three domains of teaching: Professional Knowledge, Professional Practice and Professional Engagement. They outline what teachers should know and be able to do at pre-determined career stages: graduate, proficient, highly accomplished, and lead. Furthermore, the national program's standards that will guide the accreditation process identified ICT as a particular area that needed to be addressed within the curriculum framework of courses seeking accreditation.

As such, by 2015 all Australian teacher education institutions need to be able to demonstrate how the new standards, particularly at graduate level and in ICT, are being met through their pre-service courses.

The success of the TTF proposal, in seeking funds from the Schools Division of DEEWR through the ICT Innovation fund, in many ways, can be attributed to the design of the program in producing tangible outcomes and accountabilities across these three initiatives, the DER, the Australian Curriculum, and the inaugural national accreditation of teacher education programs.

The project proposal was submitted in early 2010 as a response to the call from the especially created ICT Innovation Fund (ICTIF) for proposals "to support teachers and school leaders to embrace new technology and encourage them to creatively and effectively integrate the use of Information and Communication Technology (ICT) into the classroom" (DEEWR, 2010; p. 3). Three key outcomes were targeted for funding: (i) improving the capability of pre-service teachers, (ii) enhancing the capacity of inservice teachers; and, (iii) driving innovation through leadership. While the TTF project was keen to impact on the latter two outcomes, its prime objective lay in the first, that is, enriching the experience of pre-service teachers and, as a result, affecting practices and pedagogies in teacher education.

To initiate the project bid, a small group of academics led by Professor Toni Downes, Charles Sturt University and Chair of the Australian Council of Deans of Education, and Professor Geoff Romeo, Australian Catholic University, began conversations about what they would see as a significant way forward in promoting transformative 
change in Australian schools through the meaningful use (ICT) and the role that teacher education institutions could play in this. Numerous phone calls were made, some face to face meetings were held, and a blog was put in place, to canvass ideas and garner support across all Australian universities and other higher education providers with teacher education programs. Importantly, while framed by the extensive experience of the lead academics, the project design used a bottom-up approach to build commitment and collaboration across all of these institutions.

Eventually, a project plan emerged, one informed by research and based on a firm belief that an approach coordinated on various levels needed to be initiated. The project plan took into account the current political and educational landscape, by addressing the DER, the Australian Curriculum and the forthcoming national initial teacher education accreditation process.

Further, the project needed to be nationally focused but locally relevant. It was important to break away from existing models that did not seem to be effective in making large scale systematic change in classrooms - it had to be bold but pragmatic. What emerged was ambitious yet politically astute in its bringing together of all teacher education institutions with a common set of goals that addressed national priorities for school education - something that had never been seen before in Australia.

Before closing this section on the genesis of the program, it is important to note that there were a number of events across the educational and political landscape, which initially threatened the TTF project. These included the Australian Federal election in 2010, the devastating floods in early 2011, and the closure of the Australian Learning and Teaching Council. The 2010 national election was called for August, which coincidentally clashed with the proposed announcement of the ICTIF grants, thus postponing any decision regarding the project. The election did not produce a clear outcome and a minority government was not announced until September. All decisions ceased during this period while the new government was formed. The announcement of the successful bid was not made until November 2010. Interestingly, the end dates did not change although three months had been effectively lost to the project - this was significant as it had been planned to complete recruitment for the project before the end of the 2010 calendar year. Furthermore, one of the first tasks of the minority government was to shut down the Australian Teaching and Learning Council. This Council was a higher education agency that focused on improving quality of curriculum, learning and teaching in higher education, and had at the request of the Australian Council of Deans of Education, generously agreed to be the consortium lead in this project. This was a structural issue that the Australian Council of Deans of Education needed to address on behalf of its 39 member universities.

These events succeeded in delaying rather than halting the TTF Project. It is an indication of the shared goodwill and drive for change that the project managed to survive. In particular, Education Services Australia, one of the three consortium members, generously stepped into the breach at the point of developing contracts and agreed to be the lead institution. The delays did, however, have some flow-on effect throughout the project, particularly in reducing the lead time needed to change learning experiences in pre-service classes and in recruiting key personnel.

The paper thus far has attempted to describe the context in which the TTF Project was designed. This indicates the heightened level of change currently being experienced 
within the Australian education sector which also impacts on how teacher education institutions must now move to prepare the next generation of teachers.

\section{Structure and operations of the TTF Project}

The TTF project may appear at first to be a highly complex set of connections and interconnections between the partner agencies and each participating university. But, it is founded - quite simply - on three interdependent components supported by a community, here labeled as the National Support Network (Figure 1).

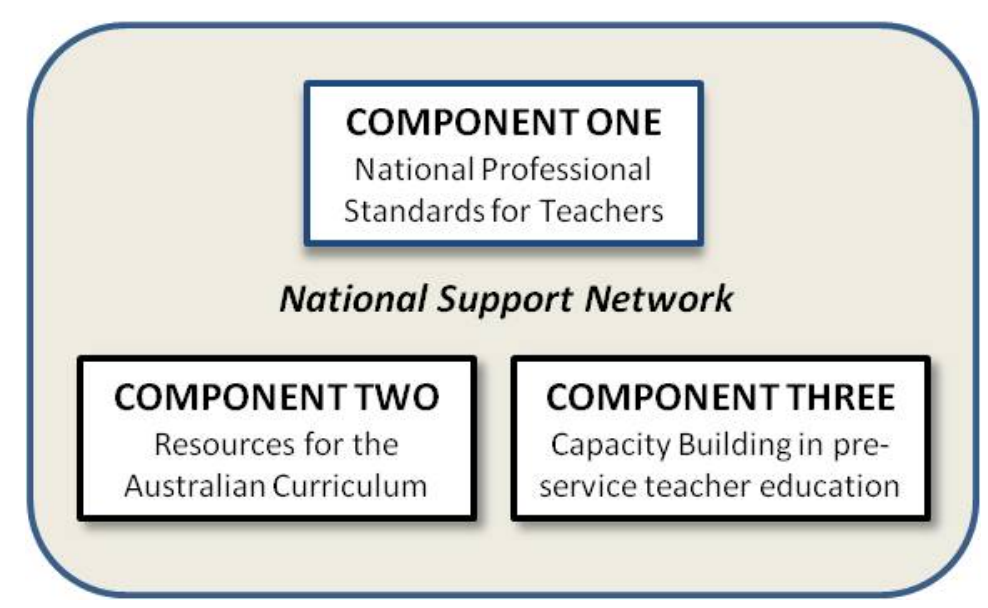

Figure 1: Organisational structure of the TTF project

\section{Component One}

This component, led by the Australian Institute for Teaching and School Leadership (AITSL) in conjunction with the Australian Council for Computers in Education (ACCE), has a direct connection to the previously discussed National Professional Standards for Teachers at graduate level. Put simply, the aim of Component One was to describe the standards in terms of ICTE. Table 1 provides two examples from Standard Three (Plan for and implement effective teaching and learning).

Table 1: Example of standards, descriptor and ICT elaboration

\begin{tabular}{|l|l|l|l|}
\hline \multicolumn{2}{|c|}{ Focus area } & \multicolumn{1}{|c|}{ Descriptor } & \multicolumn{1}{|c|}{ ICT elaboration } \\
\hline 3.2 & $\begin{array}{l}\text { Plan, structure and } \\
\text { sequence learning } \\
\text { programs }\end{array}$ & $\begin{array}{l}\text { Plan lesson sequences } \\
\text { using knowledge of } \\
\text { student learning, content } \\
\text { and effective teaching } \\
\text { strategies. }\end{array}$ & $\begin{array}{l}\text { Select and sequence digital resources and } \\
\text { tools in ways that demonstrate } \\
\text { knowledge and understanding of how } \\
\text { these can support deep learning of the } \\
\text { content of specific teaching areas and } \\
\text { effective teaching strategies. }\end{array}$ \\
\hline 3.4 & $\begin{array}{l}\text { Select and use } \\
\text { resources }\end{array}$ & $\begin{array}{l}\text { Demonstrate knowledge } \\
\text { of a range of resources, } \\
\text { including ICT, that engage } \\
\text { students in their learning. }\end{array}$ & $\begin{array}{l}\text { Demonstrate knowledge of the use of } \\
\text { digital resources and tools to support } \\
\text { students in locating, analysing, } \\
\text { evaluating and processing information } \\
\text { when engaged in learning. }\end{array}$ \\
\hline
\end{tabular}


The criticality of this seemingly simple activity becomes apparent when it is remembered that the National Professional Standards for Teachers will be used as the criteria to accredit all teacher education courses in Australia from 2015 onwards. To begin to embed these standards into university teaching practice before it becomes mandatory was regarded as a highly strategic move; one that would ideally have longer term benefits in seeing ICTE incorporated as a fundamental element of preservice teacher training.

Further, the intention, in the shorter term, was to enable pre-service teachers to map their ICTE proficiency against the graduate Standards and similarly for university academics to use the annotated Standards as a guide for developing meaningful assessments and learning experiences for students. This process began with a face to face workshop in Melbourne (February 2011) with a group comprising of expert practitioners and academics (teacher educators) convened by the ACCE on the recommendations of the state and territory professional assocations.

The tangible outcomes of Component One are clear and represent a cohesive set of print and digital resources published online [http://www.teacherstandards.aitsl .edu.au]. These are: an e-Evidence user guide, the ICT Elaborations and Annotated Illustrations of Practice which are video vignettes of pre-service and beginning teachers in the classroom. They will be publicly available to inform the professional learning of practising teachers as well as continuing to support teacher education pedagogy.

AITSL also conducted an evaluation via an online survey which was followed up by sample interviews to ascertain the effectiveness and use of the ICTE Dimensions developed through Component One. While this data was unavailable at the time of writing, interim project reports indicate an overall satisfaction with the outcomes of Component One to date, with the dimensions, although incomplete, being seen as guiding curriculum design and informing change agenda. It is known that some teacher education institutions have used the Standards in their initial audit and mapping of the pre-service teacher courses.

\section{Component Two}

The aim of Component Two, as led by Education Services Australia (ESA), was to develop a high quality collection of digital resources for pre-service teachers, teacher educators and teachers. The resources were to represent Australian classrooms and to make explicit connection to the Australian Curriculum and the National Professional Standards for Teachers.

To this end, twelve resource packages were produced, that is, one for each of the Phase 1 learning areas of the Australian Curriculum (English, Mathematics, History, and Science) for the early years, middle years and senior years of schooling. The 12 packages incorporated but were not limited to:

- Video recordings of classroom practice and interviews with both teachers and preservice teachers;

- Annotated lesson plans that illustrate meaningful use of ICT through the Australian Curriculum;

- Digital resources and professional learning in a variety of media formats; 
- Advice on the use of technologies within the pedagogical approach;

- Facility to deconstruct and repurpose resources, research articles and tools to support collaboration and planning.

Each resource is at least 30 screen pages in length and, as noted, includes purposeful classroom footage, extensive references and, importantly, the voices of pre-service teachers. An important design parameter was that the resources were to be standalone, that is, available for all pre-service teachers independent of their university programs. The resources may be found, with access limited to educators, at http://www.ttf.edu.au/

The resource packages were published in Semester 2, 2011. Available evaluation data shows that teacher education institutions are successfully accessing the resources through the e-content portal. The addition of metadata records has enabled national distribution of the resources to jurisdictions and sectors through their portals. Materials have been, and will be, repurposed for use by other national projects.

\section{Component Three}

Component Three was, put simply, about people, curriculum and pedagogy. More formally, it was about driving change, building capacity, sharing expertise and developing sustainable professional networks both within and between teacher education institutions. The more tangible outcomes of Component One (documentation around the Graduate Standards) and Component Two (exemplars of practice) were designed to support Component Three.

Through Component Three funding, senior academics with ICTE expertise were partially released from teaching duties and highly accomplished ICTE educators were seconded to work with teacher educators, particularly curriculum methods lecturers, and pre-service teachers to develop and share exemplary ICTE curriculum and resources. Titles were invented for the roles they would undertake. The senior academics were known as TTF Project Coordinators, abbreviated to TTFPC. The seconded teachers or early career academics were employed as ICT Pedagogy Officers, abbreviated as ICTPOs. What sets an ICTPO apart from those with experience of teaching about ICT is their content knowledge and experience of teaching with ICT in English, or mathematics, or science, or history. The role of the TTFPC was to mentor and assist the ICTPO and to provide strategic leadership in the institutional components of the project. It was at first presumed that each of the 39 providers - even those with multiple campuses - would appoint one TTFPC and one ICTPO. The reality has been quite different. By the end of April, 2011, there were 47 TTFPCs with 32 institutions having one, six institutions having two, and one institution having three. Sixty-eight ICTPOs had been appointed: 19 institutions had one, 13 institutions had two, 5 institutions have three and 3 institutions had four. The decision on how to allocate the funding for personnel was given to institutions and the choice for multiple appointments appears anecdotally to be based on various factors, but most typically to cover multiple campuses and differing learning areas or to rationalise workload.

Those in the institutions working within Component Three were supported through a National Support Network (NSN). The NSN connections are simple. First, there is a SharePoint site, the hub of the project, where all information is stored, a calendar is maintained, and events are recorded. Second, there are email lists used for discussion 
and reminders of milestones. Thirdly, there are face to face events. The TTF project has convened three face to face NSN workshops. At these events, plans are made and progress is shared between institutions. These have been lively events and have given project participants a further opportunity to meet and collaborate.

Component Three has achieved demonstrable success through its selection and placement of targeted personnel and meeting all project milestones to date. For example, all 39 teacher education providers have completed a broad ICT mapping of current curriculum and pedagogy practices through the review of course description documents, learning outcomes and assessment items. The interim reporting conducted thus far reveals this achievement through frequent reference to "progressing well" and the notion of "momentum" building around the project with phrases such as "ramping up" and "taking shape" being commonly used in survey responses.

There has also been a high level of acceptance of the ICT Pedagogy Officers (ICTPOs) within participating institutions, accompanied by an exceptionally high level of retention, with only three of the 39 providers reporting any change of personnel. Of particular interest has been the diversity of activity within the institutions with each designing programs best suited to their own situation.

Further, there has been a palpable energy around the project and the expected synergies within and between institutions have begun to be evidenced, particularly through the cooperation, sharing and collaboration in the project's designated online spaces. One of the most welcome findings from the interim reporting is in the sense of ongoing commitment, with frequent reference made to proposed work continuing on from the project, intended use of resources, and longer term curriculum changes being set in place. Similarly, there has been encouraging evidence of commitment and, in some instances, enthusiasm, from curriculum methods lecturers. This indicates a sense of ownership and customisation by location or content area.

Finally, interim reporting has shown recognition of the TTF project as a catalyst to broader change both within the institutions and on into classrooms. Terms such as "opportunity" and "guide" were frequently adopted giving a clear sense that this project is meeting its ambitious intention to effect systematic change.

\section{Theoretical framework}

It is important to recall that TTF was not a research project but, rather, a teaching and learning project that needed to appeal to and be understood by politicians, bureaucrats, teachers, and pre-service teachers as well as teacher educators. The underpinning theoretical framework(s) had to be accepted and to offer a move away from the tokenistic use of technology in schools, yet have credibility.

There were two main influences on the design and conduct of the project. These were: (i) the grounded practical advice provided in ICT in education practices: A capacitybuilding toolkit for teacher education institutions in the Asia-Pacific (Lim, Chai \& Churchill, 2010); and, (ii) the conceptual framework known as TPACK or technological, pedagogical and content knowledge (Koehler \& Mishra, 2008, 2009; Koehler, Mishra \& Yahya, 2007; Mishra \& Koehler, 2006). 


\section{Leading ICT in education practices: A capacity-building toolkit for teacher education institutions in the Asia-Pacific}

Initial planning for the project was influenced by the comprehensive toolkit developed by Lim et al. (2010), particularly in its Strategic Dimension Two (Program: Curriculum, Assessment and Practicum). The ICT capacity-building "toolkit" (Lim et al., 2010) has remained the guiding document for the TTF Project as it moves into the stage of planning for the future. The rubrics for measurement will be put to use nationally in the final stages of the project.

\section{TPACK}

TPACK (Technological Pedagogical Content Knowledge) is a conceptual framework for teacher education built from Shulman's (1986) understandings of pedagogical content knowledge. It brings together teachers' content knowledge, pedagogical knowledge and technological knowledge, focusing on the interactions between these three domains (Figure 2).

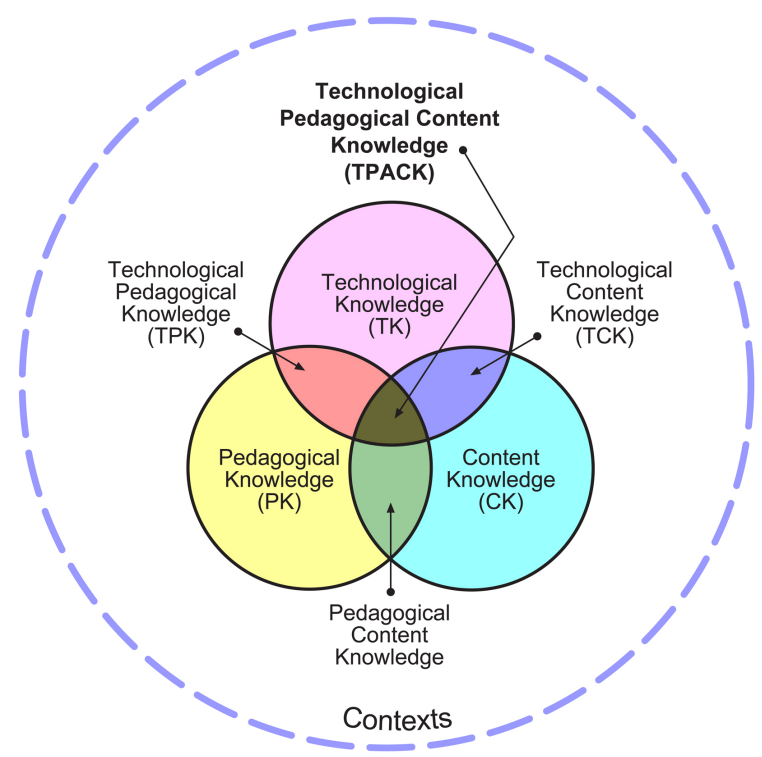

Figure 2: TPACK model (Mishra \& Koehler, n.d.)

The TPACK framework "attempts to capture some of the essential qualities of teacher knowledge required for technology integration in teaching, while addressing the complex, multifaceted, and situated nature of this knowledge" (Mishra \& Koehler, 2006; p. 1). Specifically it: highlights the nuanced and complex relationships between these three forms of knowledge; emphasises the connections, interactions and affordances, and constraints between and among content, pedagogy and technology; and influences approaches to ICT integration in curricula and in teacher education. While contested in some literature, the TPACK framework provided the TTF project with a schema for thinking about and implementing ICT in the curriculum.

In the TTF project, TPACK has been used in a number of ways, most notably, (i) to provide a framework for the resources built as part of Component Two, (ii) as the 
conceptual basis for a comprehensive national student survey (to be described in the following section), and (iii) in some instances, as the means to audit existing courses in pre-service curriculum studies (as reported in interim reports from institutions). Further, TPACK has provided a useful starting point in conversations with the curriculum methods lecturers and to move them along from the notion of ICT as an "add-on" or a simple tool for reporting or presentation of findings.

Importantly, TPACK provided the project with the language to describe the intersection and interplay of the three core elements of knowledge of content, pedagogy and technology. Importantly, it allowed the project leaders to bridge the gap between research and curriculum design and provided guidance on how to apply the ideas in education contexts, including teacher education programs, and the building of resources.

\section{Evaluation and research}

The TTF Project, while not a research project per se, provided opportunities for research at both a national and local level. Firstly, there has been a cycle of reporting to the funding body, DEEWR (Department of Education, Employment and Workplace Relations), which has been met through scheduled interim reports and face to face briefings. Evaluation has also been built into Components One and Two in quite formal ways and the measures being undertaken by the responsible agencies. For example, Component One is being evaluated by AITSL through a survey and sample interviews with a focus on how the ICTE Elaborations may be used to support the development of ICT capacities of pre-service teachers. Further, Component Two is being evaluated by ESA through a similar survey and interview process to consider the value and functionality of the developed resources as well as a more comprehensive approach that has involved pre-service teachers.

The impact of Component Three has been subject to rigorous evaluation coordinated by a specially convened Research and Evaluation Working Group. This has taken the form of two independent studies. The first is quantitative in nature and has involved extensive surveys to collect data on the perceptions of TPACK usefulness and on confidence of pre-service teachers at all levels. The second is qualitative and has made use of the Most Significant Change technique (Dart \& Davies, 2003). Its intention has been to gather rich project data through the iterative recounting of stories of practice. The following provides a summary of the key outcomes of Component Three research and evaluation.

\section{TPACK surveys}

There are a number of extant surveys and quantitative methodologies to measure the TPACK capability of pre-service teachers (see, for example, Archambault \& Crippen, 2009; Jamieson-Proctor, Finger \& Albion, 2010; Jordan, 2011). However there is still no widely accepted and generally applicable instrument for measuring teachers' TPACK. The TTF Project provided a unique opportunity to develop such an instrument that would measure the change in pre-service teachers' TPACK. The initial TPACK survey (T1) was administered throughout June-August, 2011 while the subsequent survey (T2) was administered from October to December 2011.

The aim of the surveys was to determine changes to the pre-service teachers' selfperceptions of their confidence to use ICT with a range of pedagogical strategies, as 
well as their confidence to support their students' learning with ICT. It also aimed to measure pre-service teachers' perceptions of usefulness for teaching and student learning with ICT.

A total of 12881 participants completed the first survey (T1) and 5809 participants the second (T2). Approximately $80 \%$ at T1 indicated gender and/or higher education affiliation, with about $75 \%$ completing the confidence, usefulness and other rating scale items. Participants tended to be female, Australian, spoke English at home, and tended not to identify as either Aboriginal Australians or Torres Straight Islanders. They ranged in age from 17-62 years with an average age of 29 years, and with secondary school as the most likely previous qualification for both participants and their parents.

In brief, the scale: Confidence to use ICT as a teacher showed measurable growth across the whole scale from T1 to T2. The scale: Confidence to facilitate student use of ICT also showed measurable growth across the whole scale from T1 to T2. The Usefulness scales showed no change from T1 to T2 but had registered highly in T1.

Therefore, the apparent measurable growth in both confidence to use ICT as a teacher, and in confidence to facilitate student use of ICT, in combination with higher levels of initial teacher education students' perceptions of the usefulness of ICT for them as a teacher, and their perceptions of the usefulness of ICT for their future students, might suggest that the initial teacher education students are now more likely to demonstrate TPACK as future teachers. Interestingly, the analysis of data using the individual universities as the unit of analysis found marked differences from the national project results for those universities tested. Further analyses have been recommended at the individual university level.

\section{Most significant change (MSC)}

This research strategy has allowed the gathering and sharing of rich stories at the local level to complement the quantitative data collected at the national level. It has provided a mechanism for those involved in the project to analyse the impact of their work and identify plans for the future. Each institution was required to develop an "MSC story" to complement the quantitative survey data. The stories were drawn from focus groups with pre-service teachers and teacher educators using a prepared set of focus group questions. Each focus group conversation was converted into a short two-page story that was shared online for feedback and verification.

In all, 41 stories of implementation within curriculum units including English, mathematics, science, history or integrated units were submitted. The initial analysis of these stories has identified four different categories of engagement with ICT within these courses. These four levels have been developed from examination of the stories and engagement with the literature (Hegarty \& Penman, 2005; Newhouse, Trinidad \& Clarkson, 2002). The four categories are:

- Investigation: Beginning to develop an interest in using ICT with evidence of some action by pre-service teachers and academics.

- Application: Some use of ICT by individual academics or small groups with increasing pre-service teacher engagement.

- Integration: Regular use of ICT by academics and pre-service teachers with increasing confidence and competence across whole courses or programs. 
- Extension and leadership: ICT use has become critical to support learning and academics and pre-service teachers have the ability to engage in formal and informal leadership roles supporting the use of ICT.

Further analysis of each story to identify the pattern of engagement in each category across the three domains is currently being finalised. These domains of change are: teacher educator use of ICT curriculum, pedagogy, assessment and resources in specific curriculum areas; ICT capacity of teacher educators and of pre-service teachers.

\section{Conclusion - the future of TTF}

The TTF project had both a unique opportunity and the unenviable responsibility to make the most of a rare opportunity for national funding and organisational support to make a change to how ICTE is promoted and modelled in initial teacher education across Australia. The project was also faced with challenges and opportunities posed by the current educational and political landscape of teaching and learning in Australia. Decisions - made in the present to influence the future - were designed to: develop, support and increase pre-service teacher's ability to use a range of digital technologies effectively in the classroom; build ICTE resources that would be readily available to pre-service teachers, in-service teachers and teacher educators; involve all Australian teacher education providers; link to the Australian Curriculum and National Professional Standards for Teachers and national program accreditation, and draw upon the TPACK framework by using it to underpin resource and curriculum development.

The TTF Project can be seen as a nationally significant project which has broken new ground in Australian school education and higher education. It has shown that all teacher education providers have a clear commitment to ICT pedagogy and to its integration into classrooms all around the country. This has been a watershed project marked by goodwill, commitment and sustained focus. The time was right for such a project - there is government and community backing for ICT in schools; there is a national curriculum and national teacher accreditation coming into being; and there is, because of ICT, a reduced distance between Australian teacher education institutions. It has generated significant outcomes; these outcomes need to be celebrated, critiqued and propagated.

Sustainability is more problematic. The project has always been seen as a catalyst for change in teacher education pedagogy and curriculum. When the funding ceases, how will the directions and goodwill between institutions be sustained? How will the momentum for change be sustained? How will the networks that have been established and worked so effectively, especially the networks between institutions and government agencies, be maintained and lubricated? What will happen to the significant resources that have been generated and how will they be stored and maintained? What will compel teacher education institutions to continue working in this way? How can stakeholders build on the significant investment that has already been made? These are questions that need to be answered in the closing months of the project and in the aftermath. Already discussion with government is occurring and the ACDE through its meetings and networks is working with Deans of Education to enact strategies for sustainability. 
The significance of the TTF project should not be underestimated. It is a project of its time juxtaposing with policy and national initiatives. It is also a large-scale, complex project that transcends geographical, institutional and jurisdictional boundaries to provide important outcomes. The major challenge will be to maintain the momentum.

\section{Acknowledgment}

The authors would like to acknowledge the significant work and leadership of the Australian Council of Deans of Education, Education Services Australia, the Australian Institute for Teaching and School Leadership, and the Australian Learning and Teaching Council. The Teaching Teachers for the Future project is funded by the Australian Government Department of Education, Employment, and Workplace Relations through the ICT Innovation Fund.

\section{References}

AITSL (Australian Institute for Teaching and School Leadership) (2011). National professional standards for teachers. http:/ / www.teacherstandards.aitsl.edu.au/Standards/ AllStandards

Archambault, L. \& Crippen, K. (2009). Examining TPACK among K-12 online distance educators in the United States. Contemporary issues in Technology and Teacher Education, 9(1), 71-88. http: / / www.citejournal.org/vol9/iss1/general/article2.cfm

Barak, M. (2007). Transition from traditional to ICT-enhanced learning environments in undergraduate chemistry courses. Computers $\mathcal{E}$ Education, 48(1), 30-43. http:/ / dx.doi.org/10.1016/j.compedu.2004.11.004

Dart, J. J. \& Davies, R. J. (2003). A dialogical story-based evaluation tool: The most significant change technique. American Journal of Evaluation, 24(2), 137-155. http: / / dx.doi.org/10.1177/109821400302400202

Dawson, V. (2008). Use of information communication technology by early career science teachers in Western Australia. International Journal of Science Education, 30(2), 203-219. http: / / dx.doi.org/10.1080/09500690601175551

DEEWR (Department of Education, Employment and Workplace Relations) (n.d.). Digital Education Revolution. http:/ / www.deewr.gov.au/Schooling/DigitalEducationRevolution/ Pages / default.aspx

DEEWR (Department of Education, Employment and Workplace Relations) (2010). ICT Innovation Fund Guidelines 2010-2012. http: / / www.deewr.gov.au/Schooling/DigitalEduca tionRevolution/DigitalStrategyforTeachers/Documents/ICTInnovationGuidelines.rtf

Garrett, P. (2011). Media release: $\$ 41$ million for online curriculum support to benefit teachers and students. Media release, Minister for School Education, Early Childhood and Youth, 23 September 2011. http: / / ministers.deewr.gov.au / garrett/41-million-online-curriculumsupport-benefit-teachers-and-students

Hegarty, B. \& Penman, M. (2005). Approaches and implications of eLearning adoption in relation to academic staff efficacy and working practice. Wellington: UCOL - Universal College of Learning. http: / / edcounts.squiz.net.nz /__data/assets / pdf_file/0019/58132 / ALET-final-Report-2510-06.pdf

Horne, D. (1964). The lucky country. Harmondsworth, UK: Penguin. 
Jamieson-Proctor, R., Finger, G. \& Albion, P. (2010). Auditing the TPACK capabilities of final year teacher education students: Are they ready for the 21st century? In D. Gronn \& G. Romeo (Eds), ACEC2010: Digital Diversity. Conference Proceedings of the Australian Computers in Education Conference 2010, Melbourne 6-9 April. Carlton, Victoria: Australian Council for Computers in Education (ACEC). http: / / acec2010.acce.edu.au/proposal/248/ auditingtpck-capabilities-final-year-teacher-education-students-are-they-ready-21st

Jordan, K. (2011). Beginning teacher knowledge: Results from a self-assessed TPACK survey. Australian Educational Computing, 26(1), 16-26. http:/ / acce.edu.au/journal/26/1/ beginningteacher-knowledge-results-self-assessed-tpack-survey

Koehler, M. \& Mishra, P. (2008). Introducing TPCK. In AACTE Committee on Innovation and Technology, Handbook of pedagogical content knowledge (TPCK) for educators (pp. 3-29). New York: Routledge.

Koehler, M. \& Mishra, P. (2009). What is technological pedagogical content knowledge? Contemporary Issues in Technology and Teacher Education, 9(1). http: / / www.citejournal.org/vol9/iss1/general/article1.cfm

Koehler, M., Mishra, P. \& Yahya, K. (2007). Tracing the development of teacher knowledge in a design seminar: Integrating content, pedagogy and technology. Computers $\mathcal{E}$ Education, 49(3), 740-762. http:/ / dx.doi.org/10.1016/j.compedu.2005.11.012

Lim, C. P., Chai, C. S. \& Churchill, D. (2010). Leading ICT in education practices: A capacity-building toolkit for teacher education institutions in the Asia-Pacific. Singapore: Microsoft.

Lloyd, M. \& Albion, P. (2007). Altered geometry: A new angle on teacher technophobia. Journal of Technology and Teacher Education, 17(1), 41-61. http:/ / www.editlib.org/p/26171; also at http:/ / eprints.usq.edu.au / 4992/1/Lloyd_Albion_AM.pdf

MCEETYA (Ministerial Council on Education, Employment, Training and Youth Affairs) (2008). Educational goals for young Australians. Carlton South, Australia: Curriculum Corporation. http:/ / www.mceecdya.edu.au/verve/_resources/National_Declaration_on_the_Education al_Goals_for_Young_Australians.pdf

Mishra, P. \& Koehler, M. (2006). Technological pedagogical content knowledge: A framework for teacher knowledge. Teachers College Record, 108(6), 1017-1054. http:/ / modallearners.wikis.birmingham.k12.mi.us/file/view/mishra-koehler-tcr2006.pdf

Mishra, P. \& Koehler, M. (n.d.). What is TPACK? http:/ / tpack.org/

Newhouse, P., Trinidad, S. \& Clarkson, B. (2002). Teacher professional ICT attributes: A framework. Perth: Department of Education and Training Western Australia. http: / / www.det.wa.edu.au/ education/cmis / eval/downloads/pd/framework.pdf

Romeo, G. I. (2006). Engage, empower, enable: Developing a shared vision for technology in education. In D. Hung \& M. S. Khine, Engaged learning with emerging technologies (pp. 149-175) Dordrecht, The Netherlands: Springer.

Rudd, K., Smith, S. \& Conroy, S. (2007). A digital education revolution. [not found 3 Aug 2012] http:/ / www.alp.org.au/download/now / labors_digital_education_revolution_campaign_la unch.pdf; see http: / / www.pixel.com.au/documentation/ / products / netsupport/ netsupport_school/labors_digital_education_revolution_campaign_launch.pdf

Shulman, L. S. (1986). Those who understand: Knowledge growth in teaching. Educational Researcher, 15(2), 4-14. http:/ / www.jstor.org/stable/1175860 
Authors: Professor Geoff Romeo

Associate Dean of Education (Learning and Teaching)

Faculty of Education, Australian Catholic University

115 Victoria Parade, Fitzroy Victoria 3065. Email: geoff.romeo@acu.edu.au

Web: http: / / apps.acu.edu.au/staffdirectory/index.php?geoff-romeo

Associate Professor Margaret Lloyd

Faculty of Education, Queensland University of Technology

Victoria Park Road, Kelvin Grove Qld 4059

Email: mm.lloyd@qut.edu.au Web: http:/ / staff.qut.edu.au/staff/lloydmm

Professor Toni Downes, Dean

Faculty of Education, Charles Sturt University

Boorooma Street, North Wagga NSW. Email: TDownes@csu.edu.au

Web: http:/ / www.csu.edu.au/faculty/educat/staff/profiles/dean/toni-downes

Please cite as: Romeo, G., Lloyd, M. \& Downes, T. (2012). Teaching Teachers for the Future (TTF): Building the ICT in education capacity of the next generation of teachers in Australia. In C. P. Lim \& C. S. Chai (Eds), Building the ICT capacity of the next generation of teachers in Asia. Australasian Journal of Educational Technology, 28(Special issue, 6), 949-964. http: / / www.ascilite.org.au/ajet/ajet28/romeo.html 